\title{
Healing of Postextraction Sockets Preserved With Autologous Platelet Concentrates. A Systematic Review and Meta-Analysis
}

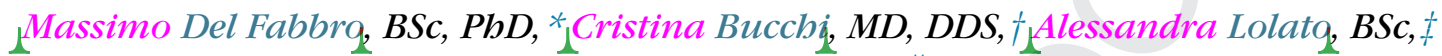

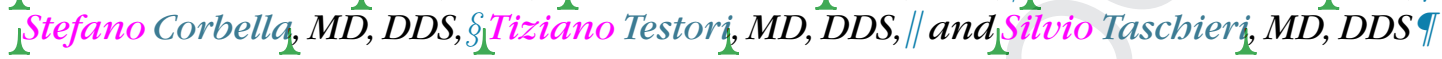

Purpose: The true benefit of autologous platelet concentrates (APCs) for enhancing the healing of postextraction sites is still a matter of debate, and in recent years several clinical trials have addressed this issue. The purpose of this study was to determine the effectiveness of an APC adjunct in the preservation of fresh extraction sockets.

Materials and Methods: An electronic search was performed on Medline, Embase, Scopus, and the Cochrane Central Register of Controlled Trials. Only controlled clinical trials or randomized clinical trials were included. Selected articles underwent risk-of-bias assessment. The outcomes were complications and adverse events, discomfort and quality of life, bone healing and remodeling assessed by histologic and radiographic techniques, and soft tissue healing.

Results: Thirty-three comparative studies were included. Nine articles had a parallel design and 24 had a split-mouth design. Twenty studies were considered to have a low risk of bias and 13 were considered to have a high risk. Overall, 1,193 teeth were extracted from 911 patients. Meta-analysis showed that soft tissue healing, probing depth at 3 months, and bone density at 1,3, and 6 month were statistically better for the APC group. Qualitative analysis suggested that APCs might be associated with a decrease in swelling and trismus. However, no relevant difference among groups was found for probing depth at 1 month, incidence of alveolar osteitis, acute inflammation or infection, percentage of new bone, and indirect measurement of bone metabolism.

Conclusion: APCs should be used in postextraction sites to improve clinical and radiographic outcomes such as bone density and soft tissue healing and postoperative symptoms. The actual benefit of APCs on decreasing on pain in extraction sockets is still not quantifiable.

(C) 2017 American Association of Oral and Maxillofacial Surgeons

J Oral Maxillofac Surg $\mathbf{\square}: 1-15,2017$

*Associate Professor, Dipartimento di Scienze Biomediche, Chirurgiche ed Odontoiatriche, Università degli Studi di Milano, Milan; Dental Clinic, IRCCS Istituto Ortopedico Galeazzi, Milan, Italy.

$\dagger$ Assistant Professor, Research Centre in Dental Sciences (CICO), Facultad de Odontología, Universidad de La Frontera, Temuco, Chile; PhD Candidate, Departamento de Patología i Terapeútica Experimental, Universitat de Barcelona, Barcelona, Spain.

$\ddagger$ PhD Candidate, Dipartimento di Scienze Biomediche, Chirurgiche ed Odontoiatriche, Università degli Studi di Milano, Milan; Dental Clinic, IRCCS Istituto Ortopedico Galeazzi, Milan, Italy.

$\S$ Visiting Professor, Dipartimento di Scienze Biomediche, Chirurgiche ed Odontoiatriche, Università degli Studi di Milano, Milan; Dental Clinic, IRCCS Istituto Ortopedico Galeazzi, Milan, Italy.

|Visiting Professor, Dipartimento di Scienze Biomediche, Chirurgiche ed Odontoiatriche, Università degli Studi di Milano, Milan; Dental Clinic, IRCCS Istituto Ortopedico Galeazzi, Milan, Italy.
ๆAcademic Researcher, Dipartimento di Scienze Biomediche, Chirurgiche ed Odontoiatriche, Università degli Studi di Milano, Milan; Dental Clinic, IRCCS Istituto Ortopedico Galeazzi, Milan, Italy. Massimo Del Fabbro and Cristina Bucchi contributed equally to this work.

Conflict of Interest Disclosures: None of the authors have any relevant financial relationship(s) with a commercial interest.

Address correspondence and reprint requests to Prof Bucchi: Universidad de La Frontera, Research Centre in Dental Sciences, Avenida Francisco Salazar 01145, Temuco, Chile; e-mail: cristina. bucchi@ufrontera.cl

Received June 242016

Accepted February 102017

(c) 2017 American Association of Oral and Maxillofacial Surgeons 0278-2391/17/30218-5

http://dx.doi.org/10.1016/i.joms.2017.02.009 


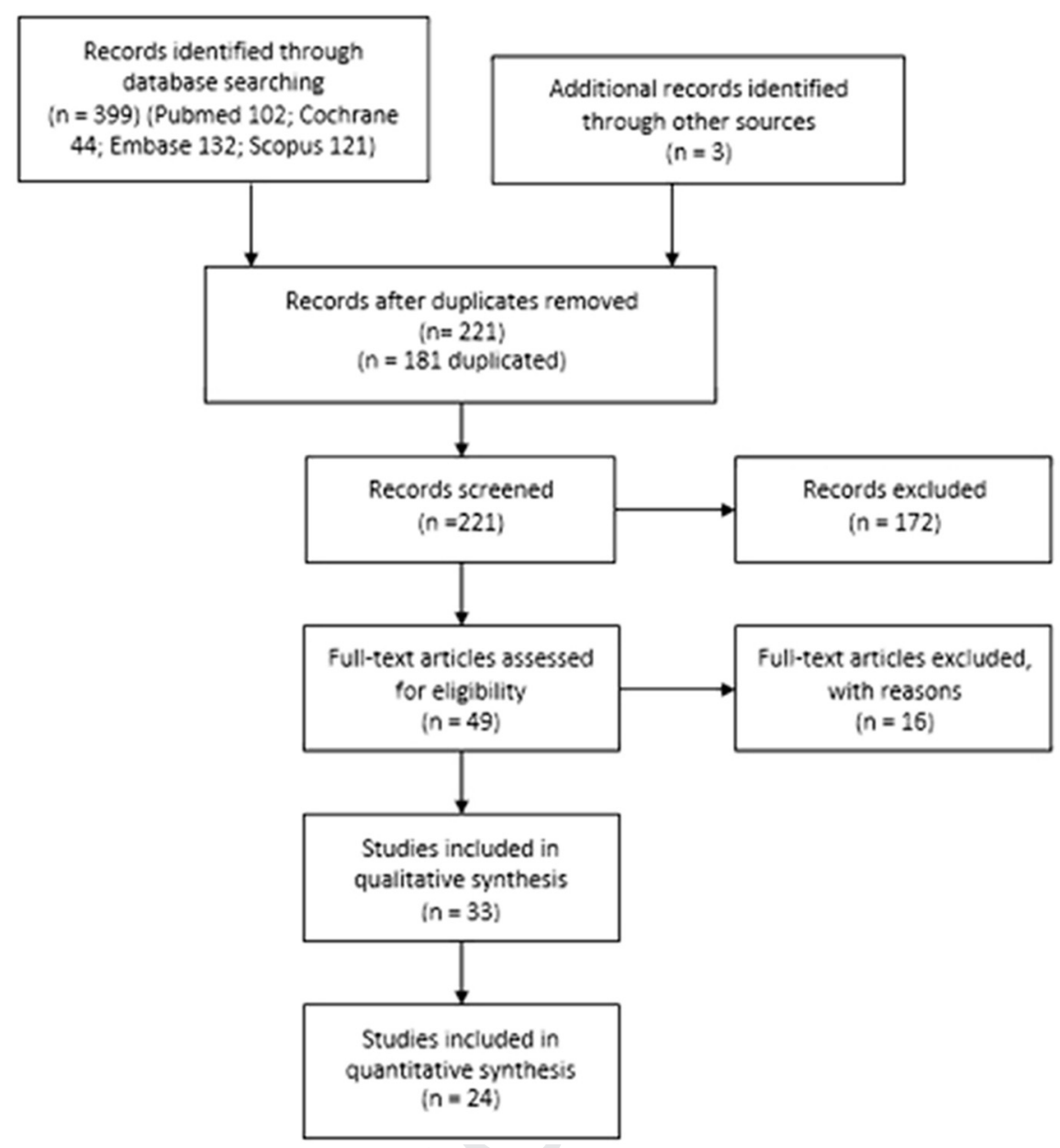

FIGURE 1. Flowchart of article selection procedure.

Del Fabbro et al. APC for Postextraction Sockets. J Oral Maxillofac Surg 2017.

Tooth extraction is one of the most frequent procedures in oral and maxillofacial surgery and is related to consistent physiologic changes to the alveolar process. The main extraction-related postoperative symptoms affecting soft tissues and patient quality of life are pain, bleeding, trismus, and swelling. Other postoperative complications are delayed healing and infection. ${ }^{1}$ Hard tissues also are affected: tooth extraction always triggers a process of bone resorption. The alveolar ridge undergoes progressive atrophy, which is more severe in the buccolingual dimension than in the apico-coronal dimension. ${ }^{2}$ Most of the resorption process occurs during the first 6 months of the postextraction period, although it continues throughout the patient's lifetime. $^{3}$

Bone loss and changes in the soft tissue profile resulting from tooth $\operatorname{loss}^{4}$ and an unpleasant esthetic aspect can hinder rehabilitation of the edentulous ridge using removable or fixed prostheses. Previous studies have found that postextraction sockets that do not undergo preservation treatment frequently require additional bone augmentation at the time of implant placement compared with postextraction sockets treated with preservation techniques. ${ }^{2}$ Many different socket preservation techniques have been proposed over the years, most of them consisting of the placement of a graft material (bone or bone substitutes) into the socket with or without the positioning of a covering membrane..$^{5-10}$ A recent systematic review reported that resorption of the alveolar ridge cannot be totally avoided, although it can be prevented with the use of alveolar ridge preservation techniques, but that no specific technique proved to be superior to another. ${ }^{11,12}$

Among the available options for decreasing postoperative symptoms and preserving postextraction sockets are autologous platelet concentrates (APCs). The most popular of such heme components are platelet-rich plasma (PRP), plasma rich in growth factors (PRGF), and platelet-rich fibrin (PRF). A common feature of all these APCs is the higher than baseline concentration of platelets, which has been shown to play an important role in tissue healing. Their effectiveness lies in the continuous and local release of a 
Table 1. MAIN CHARACTERISTICS OF INCLUDED STUDIES

\begin{tabular}{|c|c|c|c|c|c|c|c|c|}
\hline \multirow[b]{2}{*}{ Study } & \multirow{2}{*}{$\begin{array}{l}\text { Study } \\
\text { Design }\end{array}$} & \multirow{2}{*}{$\begin{array}{l}\text { Patients, } \\
\mathrm{n}\end{array}$} & \multirow{2}{*}{$\begin{array}{c}\text { Age (yr), } \\
\text { Mean (Range) }\end{array}$} & \multicolumn{2}{|c|}{ Teeth, $\mathrm{n}$} & \multicolumn{2}{|c|}{ Intervention } & \multirow[b]{2}{*}{ FU (wk) } \\
\hline & & & & Test & Control & Test & Control & \\
\hline Alissa et al, $2010^{17}$ & RCT (pa) & 23 & $30.5(20-52)$ & 15 & 14 & PRP & None & 12 \\
\hline Ogundipe et al, $2011^{18}$ & RCT (pa) & 60 & $24.7(19-35)$ & 30 & 30 & PRP & None & 16 \\
\hline Girish Rao et al, $2013^{20}$ & RCT (sm) & 22 & NR & 22 & 22 & PRF & None & 24 \\
\hline Kumar et al, $2016^{23}$ & RCT (sm) & 42 & NR (18-40) & 42 & 42 & PRF & None & 24 \\
\hline Ozgul et al, $2015^{24}$ & RCT (sm) & 56 & NR (18-28) & 56 & 56 & PRF & None & 1 \\
\hline Anitua et al, $2015^{25}$ & RCT (pa) & 60 & NR (18-74) & 36 & 24 & PRGF & None & $10-12$ \\
\hline Baslarli et al, $2015^{26}$ & RCT (sm) & 20 & $23.9(19-34)$ & 20 & 20 & PRF & None & $4-12$ \\
\hline Dutta et al, $2015^{27}$ & RCT (pa) & 60 & $\begin{array}{c}33.8 \text { PRP, } 35.3 \\
\text { control }(18-50)\end{array}$ & 30 & 30 & PRP & None & 24 \\
\hline Kumar et al, $2015^{28}$ & RCT (pa) & 31 & $26.1(19-35)$ & 16 & 15 & PRF & None & 12 \\
\hline Marenzi et al, $2015^{29}$ & RCT (sm) & 26 & 53 (NR) & & & PRF & None & 3 \\
\hline Uyanık et al, $2015^{30}$ & RCT (sm) & 10 & $22.5(19-31)$ & 10 & 10 & PRF & None & \\
\hline Cheah et al, $2014^{31}$ & CCT (pa) & 12 & $\begin{array}{c}40.7 \text { control, } \\
46.7 \text { test }\end{array}$ & 6 & 6 & $\begin{array}{l}\text { Calcium } \\
\text { sulfate + PRP }\end{array}$ & $\begin{array}{l}\text { Calcium } \\
\text { sulfate }\end{array}$ & 16 \\
\hline $\begin{array}{l}\text { Gawai and } \\
\text { Sobhana, } 2015^{32}\end{array}$ & RCT (sm) & 5 & $22.9(19-32)$ & 5 & 5 & PRP & None & 16 \\
\hline Durmuşlar et al, $2014^{33}$ & $\mathrm{CCT}(\mathrm{sm})$ & 18 & NR (18-30) & 18 & 18 & $\begin{array}{c}\text { PRP + bovine } \\
\mathrm{HA}+\mathrm{mb}\end{array}$ & $\begin{array}{l}\text { Bovine } \\
\qquad \mathrm{HA}+\mathrm{mb}\end{array}$ & 24 \\
\hline Geurs et al, $2014^{34}$ & RCT (pa) & 23 & $52(\mathrm{NR})$ & 12 & 11 & $\begin{array}{l}\text { PRP, FDBA, } \\
\text { TCP, collagen } \\
\text { plug }\end{array}$ & $\begin{array}{l}\text { FDBA, TCP, } \\
\text { collagen } \\
\text { plug }\end{array}$ & 8 \\
\hline Eshgpour et al, $2014^{35}$ & RCT (sm) & 78 & $25(18-35)$ & 78 & 78 & PRF & None & 1 \\
\hline Mozzati et al, $2014^{36}$ & RCT (sm) & 34 & 62.7 (NR) & 34 & 34 & PRGF & None & 3 \\
\hline Mozzati et al, $2014^{37}$ & CCT (sm) & 20 & $63(\mathrm{NR})$ & 57 & 57 & PRGF & None & 30 days \\
\hline $\begin{array}{l}\text { Suttapreyasri and } \\
\text { Leepong, } 2013^{38}\end{array}$ & RCT (sm) & 8 & $22.6(20-27)$ & 10 & 10 & PRF & None & 8 \\
\hline Antonello et al, $2013^{39}$ & CCT (sm) & 25 & NR (18-30) & 25 & 25 & PRP & None & 20 \\
\hline Hauser et al, $2013^{40}$ & RCT (pa) & 23 & 47.4 (NR) & $9+6$ & 8 & PRF; PRF + flap & None & 8 \\
\hline Farina et al, $2013^{41}$ & CCT (pa) & 28 & $55.2(34-74)$ & 18 & 18 & PRGF & None & $4-10$ \\
\hline Batstone et al, $2012^{42}$ & RCT (sm) & 22 & $54.5(30-68)$ & 22 & 22 & PRP & None & $5 \mathrm{yr}$ \\
\hline Célio-Mariano et al, $2012^{43}$ & RCT (sm) & 15 & NR (18-22) & 15 & 15 & PRP & None & 24 \\
\hline Haraji et al, $2012^{44}$ & CCT (sm) & 40 & $22.1(18-45)$ & 40 & 40 & PRGF & None & 4 days \\
\hline Singh et al, $2012^{45}$ & CCT (sm) & 20 & $32(18-50)$ & 20 & 20 & PRF & None & 12 \\
\hline Gürbüzer et al, $2010^{46}$ & RCT (sm) & 20 & 24.9 (NR) & 20 & 20 & PRF & None & 4 \\
\hline Mozzati et al, $2010^{47}$ & RCT (sm) & 16 & $22.5(18-35)$ & 16 & 16 & PRGF & None & 1 \\
\hline Arenaz-Búa et al, $2010^{48}$ & RCT (sm) & 34 & $23(18-45)$ & 72 & 34 & PRP & None & $12-24$ \\
\hline $\begin{array}{l}\text { Gawande and } \\
\text { Halli, 2009 }\end{array}$ & CCT (sm) & 20 & NR (18-30) & 20 & 20 & PRR & None & 24 \\
\hline $\begin{array}{l}\text { Vivek and Sripathi } \\
\text { Rao, } 2009^{50}\end{array}$ & CCT (sm) & 10 & $27(18-45)$ & 10 & 10 & PRP & None & 16 \\
\hline Gürbüzer et al, $2008^{51}$ & RCT (sm) & 12 & $21.8(\mathrm{NR})$ & 12 & 12 & PRP & None & 4 \\
\hline Sammartino et al, $2005^{52}$ & CCT (sm) & 18 & NR (21-26) & 18 & 18 & PRP & None & 18 \\
\hline
\end{tabular}

Abbreviations: CCT, clinical controlled trial; FDBA, $\mathbf{\square} \mathbf{\square}$; FU, follow-up; HA, hyaluronic acid; mb, $\mathbf{\square} \mathbf{\square}$; NR, not reported; pa, parallel design; PRF, platelet-rich fibrin; PRGF, plasma rich in growth factors; PRP, platelet-rich plasma; RCT, randomized clinical trial; sm, split-mouth design; TCP

Del Fabbro et al. APC for Postextraction Sockets. J Oral Maxillofac Surg 2017.

wide range of growth factors, which meet the needs of the physiologic process of wound healing and tissue repair. Growth factors are biological mediators capable of regulating cellular events, such as migration, cell proliferation, and differentiation in addition to synthesis of the extracellular matrix. ${ }^{13,14}$
The application of APCs for wound healing of postextraction sites has been investigated in several clinical trials. A previous evidence-based systematic review on this topic, based on strict inclusion criteria, concluded that the beneficial effects of APCs were generally but not systematically reported in most 


\begin{tabular}{|c|c|c|c|c|c|c|c|}
\hline Study & $\begin{array}{c}\text { PC } \\
\text { category }\end{array}$ & Anticoagulant & Activator & $\begin{array}{c}\text { Cycles of } \\
\text { Centrifugation }\end{array}$ & Speed (rpm) & $\begin{array}{c}\text { Centrifugation } \\
\text { Time } \\
\text { (minutes) }\end{array}$ & $\begin{array}{c}\text { Platelet } \\
\text { Count Times } \\
\text { Baseline }\end{array}$ \\
\hline Alissa et al, $2010^{17}$ & PRP & $\begin{array}{l}\text { Citrate } \\
\text { dextrose }\end{array}$ & $\begin{array}{r}\text { Autologous } \\
\text { thrombin }\end{array}$ & 1 & 3,200 & 12 & NR \\
\hline $\begin{array}{l}\text { Ogundipe } \\
\quad \text { et al, } 2011^{18}\end{array}$ & PRP & $\begin{array}{l}\text { Citrate } \\
\text { posphate } \\
\text { dextrose }\end{array}$ & $\begin{array}{l}10 \% \mathrm{CaCl}_{2}+ \\
\text { bovine } \\
\text { thrombin }\end{array}$ & 2 & $1,200+1,000$ & $10+10$ & 11.8 \\
\hline $\begin{array}{l}\text { Girish Rao } \\
\quad \text { et al, } 2013^{20}\end{array}$ & PRF & $\begin{array}{l}\text { Acidulated } \\
\text { citrate } \\
\text { dextrose }\end{array}$ & $\begin{array}{l}\text { Calcium } \\
\text { gluconate }\end{array}$ & 1 & $360-400$ & 20 & NR \\
\hline $\begin{array}{l}\text { Kumar et al, } \\
2016^{23}\end{array}$ & PRF & NA & NA & 1 & NR & NR & NR \\
\hline Ozgul et al, $2015^{24}$ & PRF & NA & NA & 1 & 3,000 & 10 & NA \\
\hline Anitua et al, $2015^{25}$ & PRGF & $\begin{array}{l}\text { Trisodium } \\
\text { citrate }\end{array}$ & $10 \% \mathrm{CaCl}_{2}$ & 1 & 1,800 & 8 & NR \\
\hline Baslarli et al, $2015^{26}$ & PRF & NA & NA & 1 & 3,000 & 10 & NR \\
\hline Dutta et al, $2015^{27}$ & PRP & $\begin{array}{l}\text { Citrate } \\
\text { phosphate } \\
\text { dextrose }\end{array}$ & $\mathrm{CaCl}_{2}$ & 2 & $2,000+3,000$ & $15+10$ & NR \\
\hline $\begin{array}{l}\text { Kumar et al, } \\
2015^{28}\end{array}$ & PRF & NA & NA & 1 & 3,000 & 10 & NR \\
\hline $\begin{array}{l}\text { Marenzi et al, } \\
2015^{29}\end{array}$ & PRF & NA & NA & & 2,700 & 12 & $\mathrm{NA}$ \\
\hline $\begin{array}{l}\text { Uyanik et al, } \\
2015^{30}\end{array}$ & PRF & NA & NA & 1 & 3,000 & 10 & NR \\
\hline $\begin{array}{l}\text { Cheah et al, } \\
2014^{31}\end{array}$ & PRP & $\begin{array}{l}\text { Citrate } \\
\text { dextrose }\end{array}$ & NR & 2 & NR & NR & $8-10$ \\
\hline $\begin{array}{l}\text { Gawai and } \\
\quad \text { Sobhana, } 2015^{32}\end{array}$ & PRP & CPDA & $\mathrm{CaCl}_{2}$ & 2 & $2,400+3,600$ & $10+10$ & 1.5 \\
\hline $\begin{array}{l}\text { Durmuşlar } \\
\quad \text { et al, } 2014^{33}\end{array}$ & PRP & $\begin{array}{l}\text { Trisodium } \\
\text { citrate }\end{array}$ & NR & 2 & $2,400+3,600$ & $10+15$ & NR \\
\hline Geurs et al, $2014^{34}$ & PRP & NR & NR & NR & NR & NR & NR \\
\hline $\begin{array}{l}\text { Eshgpour } \\
\quad \text { et al, } 2014^{35}\end{array}$ & PRF & NA & NA & 1 & 3,000 & 10 & $\mathrm{NA}$ \\
\hline $\begin{array}{l}\text { Mozzati et al, } \\
2014^{36}\end{array}$ & PRGF & $\begin{array}{l}\text { Trisodium } \\
\text { citrate }\end{array}$ & $\mathrm{CaCl}_{2}$ & 1 & 1,800 & 8 & NR \\
\hline $\begin{array}{l}\text { Mozzati et al, } \\
2014^{37}\end{array}$ & PRGF & $\begin{array}{l}\text { Trisodium } \\
\text { citrate }\end{array}$ & $\mathrm{CaCl}_{2}$ & 1 & 1,800 & 8 & NR \\
\hline $\begin{array}{l}\text { Suttapreyasri and } \\
\text { Leepong, } 2013^{38}\end{array}$ & PRF & NA & NA & 1 & 3,000 & 10 & NA \\
\hline $\begin{array}{l}\text { Antonello et al, } \\
2013^{39}\end{array}$ & PRGFmod & $\begin{array}{l}3.8 \% \text { sodium } \\
\text { citrate }\end{array}$ & $\begin{array}{c}\text { Autogenous } \\
\text { thrombin }\end{array}$ & 1 & 1,200 & 10 & $4-6$ \\
\hline Hauser et al, $2013^{40}$ & PRF & NA & NA & 1 & 2,700 & 12 & NA \\
\hline Farina et al, $2013^{41}$ & PRGF & $\begin{array}{l}\text { Trisodium } \\
\text { citrate }\end{array}$ & $\mathrm{CaCl}_{2}$ & 1 & 1,800 & 8 & NR \\
\hline $\begin{array}{l}\text { Batstone et al, } \\
2012^{42}\end{array}$ & PRP & NR & $\mathrm{CaCl}_{2}$ & NR & NR & NR & NR \\
\hline $\begin{array}{l}\text { Célio-Mariano } \\
\text { et al, } 2012^{43}\end{array}$ & PRP & $\begin{array}{l}3.2 \% \text { sodium } \\
\text { citrate }\end{array}$ & $10 \% \mathrm{CaCl}_{2}$ & 2 & $160+400 g$ & $20+15$ & $5.3-5.6$ \\
\hline Haraji et al, $2012^{44}$ & PRGF & $\begin{array}{l}\text { Trisodium } \\
\text { citrate }\end{array}$ & $\mathrm{CaCl}_{2}$ & 1 & 1,800 & 8 & NR \\
\hline Singh et al, $2012^{45}$ & PRF & - & - & 1 & 3,000 & 10 & NR \\
\hline $\begin{array}{l}\text { Gürbüzer et al, } \\
2010^{46}\end{array}$ & PRF & NA & NA & 1 & 2,030 & 10 & - \\
\hline $\begin{array}{l}\text { Mozzati et al, } \\
2010^{47}\end{array}$ & PRGF & $\begin{array}{l}\text { Trisodium } \\
\text { citrate }\end{array}$ & $\mathrm{CaCl}_{2}$ & 1 & 1,800 & 8 & NR \\
\hline
\end{tabular}


Table 2. Cont'd

\begin{tabular}{|c|c|c|c|c|c|c|c|}
\hline Study & $\begin{array}{c}\text { PC } \\
\text { category }\end{array}$ & Anticoagulant & Activator & $\begin{array}{c}\text { Cycles of } \\
\text { Centrifugation }\end{array}$ & Speed (rpm) & $\begin{array}{c}\text { Centrifugation } \\
\text { Time } \\
\text { (minutes) }\end{array}$ & $\begin{array}{c}\text { Platelet } \\
\text { Count Times } \\
\text { Baseline }\end{array}$ \\
\hline $\begin{array}{l}\text { Arenaz-Búa } \\
\quad \text { et al, } 2010^{48}\end{array}$ & PRP & NR & NR & 2 & NR & NR & NR \\
\hline $\begin{array}{l}\text { Gawande and } \\
\text { Halli, 2009 }\end{array}$ & PRP & $\begin{array}{l}\text { Citrate } \\
\text { phosphate } \\
\text { dextrose }\end{array}$ & $\begin{array}{l}\text { Autologous } \\
\text { thrombin }+ \\
\mathrm{CaCl}_{2}\end{array}$ & 2 & $1,200+2,000$ & $10+0$ & NR \\
\hline $\begin{array}{l}\text { Vivek and Sripathi } \\
\text { Rao, } 2009^{50}\end{array}$ & PRP & $\begin{array}{l}\text { Citrate } \\
\text { phosphate } \\
\text { dextrose }\end{array}$ & $\mathrm{CaCl}_{2}$ & 2 & NR & NR & NR \\
\hline $\begin{array}{l}\text { Gürbüzer } \\
\quad \text { et al, } 2008^{51}\end{array}$ & PRP & $\begin{array}{l}\text { Citrate } \\
\text { phosphate } \\
\text { dextrose }\end{array}$ & $\mathrm{CaCl}_{2}$ & 2 & $2,400+3,600$ & $10+15$ & 6.8 \\
\hline $\begin{array}{l}\text { Sammartino } \\
\text { et al, } 2005^{52}\end{array}$ & PRP & $\begin{array}{l}\text { Trisodium } \\
\text { citrate }\end{array}$ & $\begin{array}{l}\text { Batroxobin }+ \\
\text { gluconate } \\
\text { of calcium }\end{array}$ & 1 & 1,200 & 15 & NR \\
\hline
\end{tabular}

Abbreviations: $\mathrm{CaCl}_{2}$, calcium chloride; CPDA, $\mathbf{\square} \mathbf{\square}$; NA, $\mathbf{\square} \mathbf{\square}$; NR, not reported; PC, platelet concentrate; PRF, plateletrich fibrin; PRGF, plasma rich in growth factors; PRGFmod, modified plasma rich in growth factors; PRP, platelet-rich plasma. $\mathrm{Q}^{6}$

Del Fabbro et al. APC for Postextraction Sockets. J Oral Maxillofac Surg 2017.

studies. ${ }^{15}$ The main advantages associated with the use of APCs were better epithelialization of soft tissue, ${ }^{16}$ less pain, ${ }^{17}$ less swelling and trismus, ${ }^{18}$ faster alveolar bone formation, ${ }^{18}$ more mature bone, and better organized trabeculae. ${ }^{16}$ In contrast, some studies suggested there were no benefits in using APCs, because no changes were found in the horizontal or vertical dimension of the alveolar ridge $^{19}$ or in bone density. ${ }^{20}$

The objective of this updated systematic review was to evaluate relevant, well-designed studies dealing with postextraction sockets preserved with APCs and their effect on alveolar bone preservation, soft tissue healing, and a patient's quality of life.

\section{Materials and Methods}

\section{SEARCH STRATEGY}

This review was written and conducted according to Preferred Reporting Items for Systematic Reviews and Meta-Analyses (PRISMA) guidelines. ${ }^{21}$

The focus question was, "Does the adjunct of APCs produce benefits to postextraction socket healing for hard and soft tissue parameters, postoperative complications, and patient's postoperative quality of life?"

The electronic search was performed using Medline, Embase, Scopus, and the Cochrane Central Register of Controlled Trials (CENTRAL). The following terms were used for the search: (platelet rich plasma

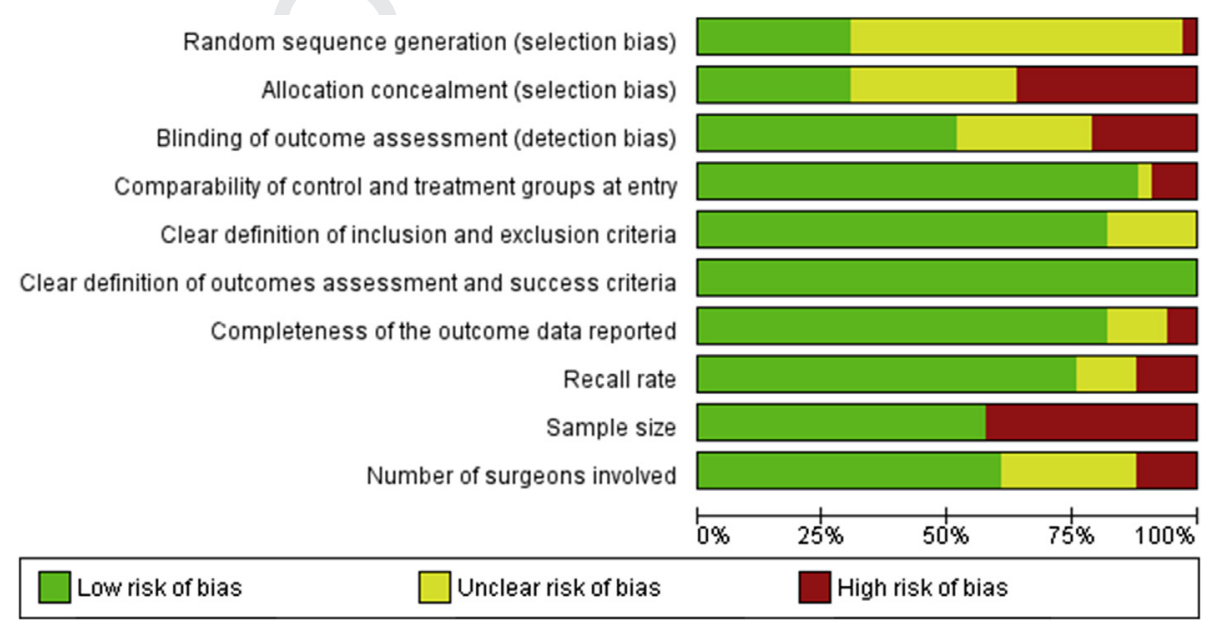

FIGURE 2. Risk-of-bias summary of included studies. 
Table 3. TOOTH TYPE, OUTCOMES, AND EVALUATION ASSESSMENT OF INCLUDED STUDIES

\begin{tabular}{|c|c|c|c|c|}
\hline Study & Tooth Type & Evaluation Assessment & Outcomes & APC Effects \\
\hline Alissa et al, $2010^{17}$ & Various & $\begin{array}{l}\text { Clinical, Rx, health-related quality of life } \\
\text { questionnaire, soft tissue healing }\end{array}$ & $\begin{array}{l}\text { Pain at 1-3 days; analgesic consumption at } \\
1,2 \text { days; bad taste, bad smell, food } \\
\text { stagnation, and alteration to diet; fewer } \\
\text { complications; soft tissue healing; } \\
\text { better distribution of trabecular bone } \\
\text { pattern }\end{array}$ & $\begin{array}{l}\text { NSD for patient satisfaction } \\
\text { with treatment and } \\
\text { trabecular dimension }\end{array}$ \\
\hline Ogundipe et al, $2011^{18}$ & Impacted 38 or 48 & Pain, clinical, $\mathrm{Rx}$ & Less pain & $\begin{array}{l}\text { NSD for bone density, } \\
\text { swelling, trismus }\end{array}$ \\
\hline Girish Rao et al, $2013^{20}$ & 38 and 48 & Radio-Visio Graphic, Rx & NSD in bone regeneration & \\
\hline Kumar et al, $2016^{23}$ & Impacted 38 and 48 & Pain, complications, $\mathbf{R x}$ & Less pain & NSD for quantity of bone \\
\hline Ozgul et al, $2015^{24}$ & Impacted 38 and 48 & Pain, swelling & Less swelling & NSD for pain \\
\hline Anitua et al, $2015^{25}$ & $\begin{array}{l}\text { Nonimpacted } \\
\text { mandibular molars }\end{array}$ & $\begin{array}{l}\text { Clinical, } \mathrm{Rx}, \text { histology, } \\
\text { histomorphometry, pain, } \\
\text { inflammation, complications }\end{array}$ & $\begin{array}{l}\text { Enhanced healing of sockets and soft } \\
\text { tissue }\end{array}$ & \\
\hline Baslarli et al, $2015^{26}$ & Impacted 38 and 48 & Osteoblast activity by scintigraphy & NSD & \\
\hline Dutta et al, $2015^{27}$ & 38 and 48 & $\begin{array}{l}\text { Soft tissue healing, dry socket, bone } \\
\text { regeneration, density, trabecular } \\
\text { formation, postoperative discomfort }\end{array}$ & $\begin{array}{l}\text { Improved hard and soft tissue healing, } \\
\text { bone density, caused less discomfort }\end{array}$ & \\
\hline Kumar et al, $2015^{28}$ & Impacted 38 and 48 & Pain, swelling, PPD, Rx, OPG & Less pain, swelling, trismus, PPD & NSD for bone density \\
\hline Marenzi et al, $2015^{29}$ & Canine to molar & Pain, soft tissue healing index & $\begin{array}{l}\text { Less pain, better healing, faster socket } \\
\text { closure }\end{array}$ & \\
\hline Uyanık et al, $2015^{30}$ & Impacted 38 and 48 & Pain, analgesics, trismus, swelling & Less pain and trismus & \\
\hline Cheah et al, $2014^{31}$ & Nonmolar teeth & CBCT, histology, histomorphometry & Higher mineralized bone content & $\begin{array}{l}\text { NSD for vertical and } \\
\text { horizontal aspects of ridge }\end{array}$ \\
\hline Gawai and Sobhana, $2015^{32}$ & Impacted 38 and 48 & Clinical, Rx (OPG) & $\begin{array}{l}\text { Greater bone density at } 1 \text { mo but not at } \\
4 \mathrm{mo}\end{array}$ & Improved soft tissue healing \\
\hline Durmuşlar et al, $2014^{33}$ & Impacted 38 and 48 & PD, PPD, clinical, Rx (OPT) & $\begin{array}{l}\text { Greater bone density at } 3 \text { mo but not at } 1 \\
\text { and } 6 \text { mo }\end{array}$ & NSD for PPD \\
\hline Geurs et al, $2014^{34}$ & Anterior, premolars & Histomorphometry & Increased bone graft turnover & \\
\hline Eshgpour et al, $2014^{35}$ & Impacted 38 and 48 & Clinical & Less alveolar osteitis & \\
\hline Mozzati et al, $2014^{36}$ & NR & $\begin{array}{l}\text { Residual socket volume, pain, healing } \\
\text { index, complications }\end{array}$ & $\begin{array}{l}\text { Better healing index, smaller residual } \\
\text { socket volume (pain results NR) }\end{array}$ & \\
\hline Mozzati et al, $2014^{37}$ & Various & $\begin{array}{l}\text { Residual socket volume, pain, healing } \\
\text { index, complications }\end{array}$ & $\begin{array}{l}\text { Better healing index, smaller residual } \\
\text { socket volume, less complications } \\
\text { (pain results NR) }\end{array}$ & \\
\hline $\begin{array}{l}\text { Suttapreyasri and } \\
\text { Leepong, } 2013^{38}\end{array}$ & Premolar & Clinical, $\mathrm{Rx}$ & $\begin{array}{l}\text { Sooner soft tissue healing, less horizontal } \\
\text { resorption }\end{array}$ & $\begin{array}{l}\text { NSD for mesial and distal } \\
\text { resorption and bone } \\
\text { healing }\end{array}$ \\
\hline Antonello et al, $2013^{39}$ & Impacted 38 and 48 & $\mathrm{Rx}$ & Greater bone density & \\
\hline
\end{tabular}




\begin{tabular}{|c|c|c|c|c|}
\hline Hauser et al, $2013^{40}$ & Premolars & Histomorphometry, micro-CT, clinical & $\begin{array}{l}\text { NSD for bone volume, trabecular } \\
\text { thickness, intrinsic bone quality }\end{array}$ & $\begin{array}{l}\text { More trabeculae and } \\
\text { preservation of alveolar } \\
\text { width }\end{array}$ \\
\hline Farina et al, $2013^{41}$ & Various & Micro-CT, histomorphometric markers & No increase in bone deposition & \\
\hline Batstone et al, $2012^{42}$ & $\begin{array}{l}\text { Posterior } \\
\text { mandibular teeth }\end{array}$ & $\begin{array}{l}\text { Prevention of osteoradionecrosis, pain, } \\
\text { soft tissue healing }\end{array}$ & $\begin{array}{l}\text { NSD for prevention of } \\
\text { osteoradionecrosis, pain scores, or } \\
\text { mucosal healing }\end{array}$ & \\
\hline Célio-Mariano et al, $2012^{43}$ & Impacted 38 and 48 & $R \mathbf{x}$ & Faster bone formation & \\
\hline Haraji et al, $2012^{44}$ & 38 and 48 & Alveolar osteitis, pain, healing score & $\begin{array}{l}\text { Decreased alveolar osteitis, pain, } \\
\text { accelerated healing }\end{array}$ & \\
\hline Singh et al, $2012^{45}$ & 38 and 48 & Pain, soft tissue healing, $R x$ & $\begin{array}{l}\text { Better soft tissue healing, greater bone } \\
\text { density at } 3 \text { mo }\end{array}$ & NSD for pain \\
\hline Gürbüzer et al, $2010^{46}$ & Impacted 38 and 48 & $\begin{array}{l}\text { Scintigraphic evaluation of early } \\
\text { osteoblastic activity }\end{array}$ & NSD & \\
\hline Mozzati et al, $2010^{47}$ & Impacted 38 and 48 & Pain, swelling & $\begin{array}{l}\text { Less inflammation and better healing } \\
\text { parameters }\end{array}$ & \\
\hline Arenaz-Búa et al, $2010^{48}$ & Impacted 38 and 48 & Clinical, pain, $\mathbf{R x}$ & Inadequate report & \\
\hline Gawande and Halli, $2009^{49}$ & Impacted 38 and 48 & Pain, swelling, Rx, OPG & Less swelling, greater bone density & NSD for pain \\
\hline Vivek and Sripathi Rao, $2009^{50}$ & Impacted 38 and 48 & Pain, healing index, $R x$ & NSD for pain & $\begin{array}{l}\text { Better soft tissue healing, } \\
\text { greater density, trabecular } \\
\text { bone formation at } 12 \mathrm{wk}\end{array}$ \\
\hline Gürbüzer et al, $2008^{51}$ & Impacted 38 and 48 & $\begin{array}{l}\text { Scintigraphic evaluation of early } \\
\text { osteoblastic activity }\end{array}$ & NSD & \\
\hline Sammartino et al, $2005^{52}$ & Impacted 38 and 48 & Histology (only in APC group), clinical & Decrease of PPD, improvement of CAL & \\
\hline
\end{tabular}

Note: All outcomes were statistically significant unless otherwise specified.

Abbreviations: APC, autologous platelet concentrate; CAL, clinical attachment level; CBCT, cone-beam computed tomography; micro-CT, micro-computed tomography; NR, not reported; NSD, no significant differences; OPG, orthopantomography; PPD, periodontal probing depth; Rx, radiography; VAS, visual analog scale.

Del Fabbro et al. APC for Postextraction Sockets. J Oral Maxillofac Surg 2017.

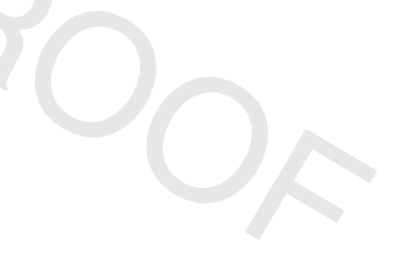




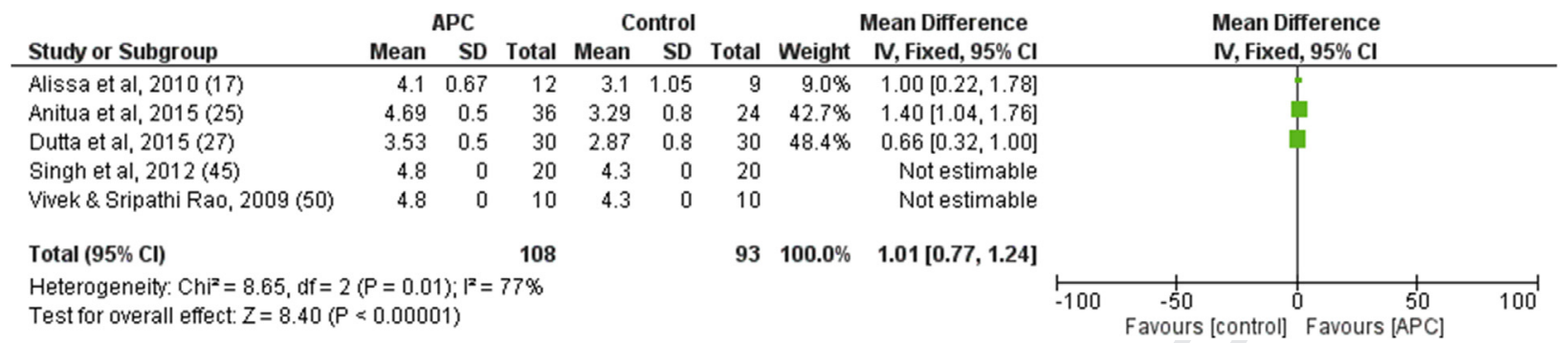

FIGURE 3. Meta-analysis of studies evaluating soft tissue healing using the index of Landry at postoperative day 7 . APC, autologous platelet concentrate; $\mathrm{Cl}$, confidence interval; $\mathrm{SD}$, standard deviation.

Del Fabbro et al. APC for Postextraction Sockets. J Oral Maxillofac Surg 2017.

OR platelet rich fibrin OR plasma rich in growth factors OR platelet concentrates OR PRF OR PRP OR PRGF) AND (postextraction sockets OR extraction sockets OR preservation techniques OR tooth extraction OR third molar surgery). In addition, a hand search was performed in the following dental journals: British Dental Journal, British Journal of Oral and Maxillofacial Surgery, Clinical Implant Dentistry and Related Research, Clinical Oral Implants Research, Clinical Oral Investigations, European Journal of Oral Sciences, Implant Dentistry, International Journal of Oral and Maxillofacial Implants, International Journal of Oral and Maxillofacial Surgery, International Journal of Periodontics and Restorative Dentistry, Journal of Clinical Periodontology, Journal of Dental Research, Journal of Dentistry, Journal of Maxillofacial and Oral Surgery, Journal of Oral and Maxillofacial Surgery, Journal of Periodontal Research, Journal of Periodontology, and Oral Surgery, Oral Medicine, Oral Pathology, and Oral Radiology. The reference lists of the included studies and of the reviews also were searched for possible additional eligible studies.

The last electronic search was performed on February 8, 2016.

\section{INCLUSION CRITERIA}

The selection criteria were limited to clinical studies involving human subjects. To be included the articles had to be controlled clinical trials or randomized clinical trials, have a parallel or split-mouth design, and have a sample size of at least 5 patients per group or 5 patients with bilateral treatment.

The studies had to use any APC in the postextraction sockets of the experimental group. The APC could be used alone or in conjunction with another material (such as bone graft materials), but the only difference between the control and experimental groups had to be the use of APC. The studies had to provide clear and adequate information on all agents and techniques used for socket preservation procedures.

No restrictions on language or follow-up duration were applied.

\section{SELECTION OF STUDIES AND DATA COLLECTION}

Titles and abstracts of the articles retrieved by the electronic search were screened by 2 independent reviewers (C.B. and S.C.). Two reviewers checked whether they met the inclusion criteria and independently assessed the full text of studies of possible relevance. Cases of disagreement were resolved by discussion. Reasons for exclusion were recorded.

Two independent reviewers extracted the relevant data using an Excel spreadsheet (Microsoft, Redmond, WA). The extracted data were study design, study setting, ethical approval, country, number of patients and sockets in the control and experimental groups, mean age of patients, intervention, follow-up duration, tooth type, reason for extraction, number of dropouts, and information on the method of APC production. Additional extracted data on outcome variables were adverse events, patient satisfaction, self-reported

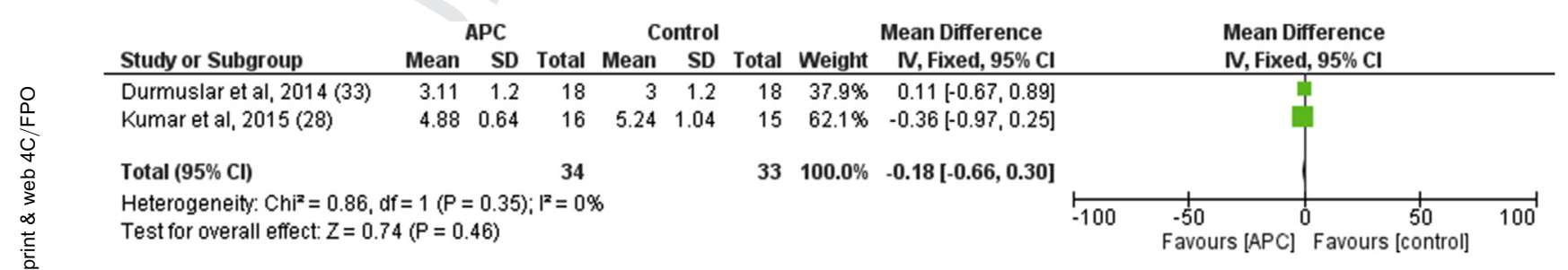

FIGURE 4. Meta-analysis of studies evaluating probing depth at the first postoperative month. APC, autologous platelet concentrate; $\mathrm{Cl}$, confidence interval; SD, standard deviation. 
DEL FABBRO ET AL

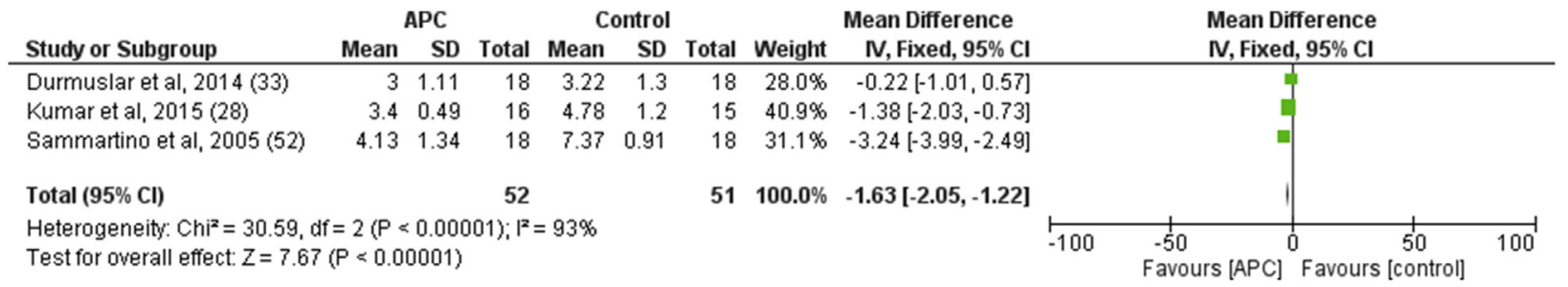

FIGURE 5. Meta-analysis of studies evaluating probing depth at this third postoperative month. APC, autologous platelet concentrate; $\mathrm{Cl}$, confidence interval; SD, standard deviation.

Del Fabbro et al. APC for Postextraction Sockets. J Oral Maxillofac Surg 2017.

postoperative quality of life (including pain, swelling, and other symptoms, assessed through a questionnaire or interview), radiographic evaluation of bone healing, clinical or radiographic evaluation of marginal bone remodeling, and soft tissue healing.

The primary outcome measurements were:

- Any complication and adverse event (eg, alveolar osteitis, acutely infected or inflamed alveolus)

- Postoperative discomfort and quality of life (eg, self-reported postoperative pain on a visual analog scale, swelling)

Secondary outcome measurements were:

- Bone healing assessed radiographically (eg, by evaluation of bone density or trabecular bone pattern at the extraction site) or histomorphometrically (eg, assessment of percentage of bone volume)

- Clinical or radiographic evaluation of marginal bone remodeling (eg, bone height at the vestibular and lingual or palatal aspect and bone width at the extraction region)

- Any other indirect estimation of bone regeneration process (eg, through evaluation of markers of bone metabolism, osteoblast activity)
- Clinical evaluation of soft tissue healing (eg, using the healing index proposed by Landry or other standard indices)

\section{RISK OF BIAS ASSESSMENT}

The methodologic quality of the selected studies was evaluated independently by 2 reviewers (C.B. and M.D.F.), according to the following methodologic parameters.

Randomized Studies

- Random sequence generation method and allocation concealment

All Studies

- Calibration and blinding of outcome assessment

- Comparability of control and treatment groups at entry

- Clear definition of inclusion and exclusion criteria

- Clear definition of outcomes assessment and success criteria

- Completeness of the outcome data reported and explanation for dropouts or withdrawal (when applicable)

- Recall rate (it was assumed adequate if the dropout rate was $<10 \%$ )

Risk Ratio Risk Ratio

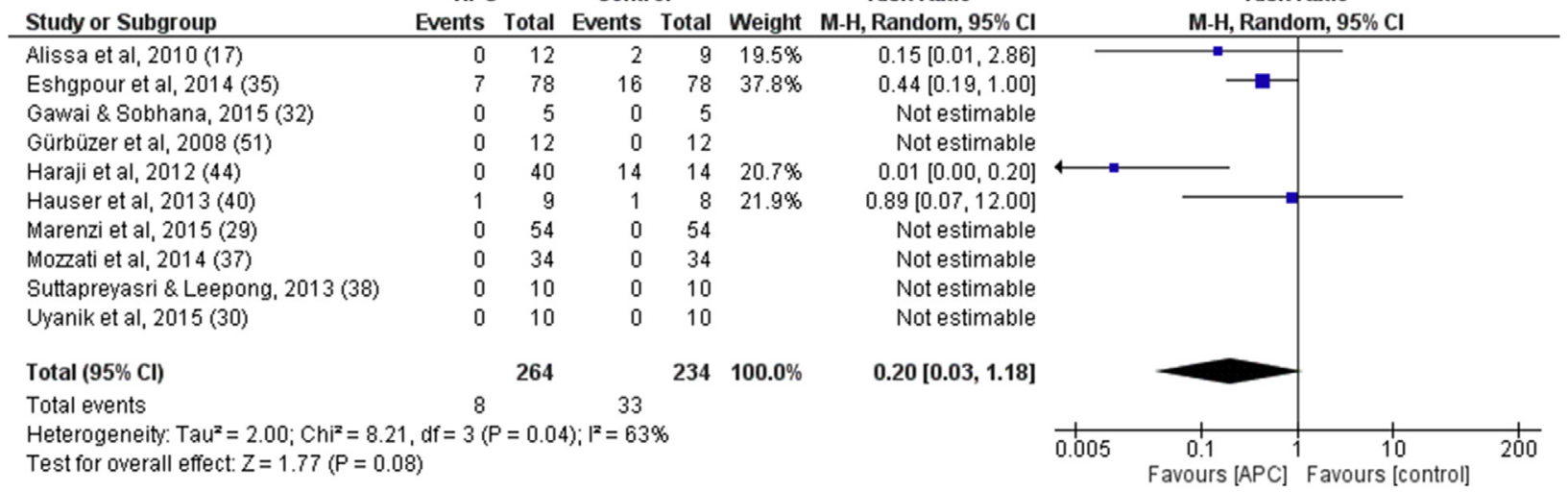

FIGURE 6. Meta-analysis of studies evaluating incidence of alveolar osteitis. APC, autologous platelet concentrate; $\mathrm{Cl}$, confidence interval. Del Fabbro et al. APC for Postextraction Sockets. J Oral Maxillofac Surg 2017. 


\begin{tabular}{|c|c|c|c|c|c|c|c|c|c|}
\hline Study or Subgroup & \multicolumn{2}{|c|}{ APC } & \multicolumn{2}{|c|}{ Control } & Weight & $\begin{array}{l}\text { Risk Ratio } \\
\text { M-H, Random, } 95 \% \mathrm{Cl}\end{array}$ & \multicolumn{3}{|c|}{$\begin{array}{c}\text { Risk Ratio } \\
\text { M-H, Random, } 95 \% \mathrm{Cl}\end{array}$} \\
\hline Alissa et al, 2010 (17) & 0 & 12 & 1 & 9 & $24.9 \%$ & $0.26[0.01,5.65]$ & 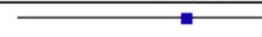 & & \\
\hline Anitua et al, 2015 (25) & 0 & 36 & 0 & 24 & & Not estimable & & & \\
\hline Barslarli et al, 2015 (26) & 0 & 20 & 2 & 20 & $26.9 \%$ & $0.20[0.01,3.92]$ & & & \\
\hline Gürbüzer et al, 2008 (51) & 0 & 12 & 0 & 12 & & Not estimable & & & \\
\hline Gürbüzer et al, 2010 (46) & 0 & 16 & 1 & 16 & $24.4 \%$ & $0.33[0.01,7.62]$ & & & \\
\hline Hauser et al, 2013 (49) & 0 & 9 & 0 & 8 & & Not estimable & & & \\
\hline Kumar et al, 2016 (23) & 0 & 34 & 1 & 34 & $23.8 \%$ & $0.33[0.01,7.91]$ & & & \\
\hline Mozzati et al, 2014b (37) & 0 & 34 & 0 & 34 & & Not estimable & & & \\
\hline Suttapreyasri \& Leepong, 2013 (38) & 0 & 10 & 0 & 10 & & Not estimable & & & \\
\hline Uyanik et al, 2015 (30) & 0 & 10 & 0 & 10 & & Not estimable & & & \\
\hline Total $(95 \% \mathrm{Cl})$ & & 247 & & 231 & $100.0 \%$ & $0.27[0.06,1.27]$ & & & \\
\hline Total events & 0 & & 5 & & & & & & \\
\hline \multicolumn{7}{|c|}{$\begin{array}{l}\text { Heterogeneity: } \text { Tau }^{2}=0.00 ; \mathrm{Chi}^{2}=0.07, \mathrm{df}=3(\mathrm{P}=0.99) ; \mathrm{I}^{2}=0 \% \\
\text { Test for overall effect: } Z=1.65(\mathrm{P}=0.10)\end{array}$} & $\begin{array}{l}0.1 \\
\text { Favours [APC] }\end{array}$ & $\begin{array}{cc}10 \\
\text { Favours [control] }\end{array}$ & 100 \\
\hline
\end{tabular}

FIGURE 7. Meta-analysis of studies evaluating acute inflammation or infection of the alveolus. APC, autologous platelet concentrate; $\mathrm{Cl}$, confidence interval.

Del Fabbro et al. APC for Postextraction Sockets. J Oral Maxillofac Surg 2017.

- Sample size (it was considered adequate if $\geq 20$ patients per group were treated)

- Number of surgeons involved (it was considered adequate if the same surgeon performed all operations)

For missing or unclear data, the investigators were contacted to provide additional data or clarification.

All criteria were assessed as adequate, unclear, or inadequate except for the last 3 that were simply judged as adequate or inadequate. Criteria for assessing the risk of bias of randomized clinical trials in the present review were adapted from guidelines reported in the Cochrane Handbook for Systematic Reviews of Interventions Version 5.1.0. ${ }^{22}$ Cases of disagreement were resolved by discussion. To summarize the validity of the studies, they were considered to have a low risk of bias if at least two thirds of the parameters were judged as adequate, and they were considered to have a high risk if less than two thirds of the parameters judged as adequate were considered to have a high risk of bias.

\section{DATA ANALYSIS}

The data from different studies were combined by meta-analysis only in the presence of studies with similar comparisons reporting the same outcome measurements at comparable observation times after tooth extraction. For each trial, for dichotomous outcomes (such as postoperative alveolar osteitis, recorded as yes or no), the estimation of the effect of an intervention was expressed as risk ratios (RRs) with $95 \%$ confidence intervals (CIs). For continuous outcomes (such as percentage of newly formed bone, alveolar bone height, and width changes), mean differences with 95\% CIs were used to synthesize data for each treatment group. The statistical analysis unit, if possible, was the patient, unless all compared studies expressed the results as a function of the tooth. If a meta-analysis was not feasible for a given outcome, then a qualitative report of the results was provided.

RRs for dichotomous data and mean differences for continuous data were combined using random-effects models if at least 4 studies could be included in the meta-analysis, whereas a fixed-effects model was adopted if there were fewer than 4 studies. Review Manager 5.3 (The Nordic Cochrane Center, The Cochrane Collaboration, Copenhagen, Denmark) was used for meta-analysis calculations and graphs. Data from split-mouth and parallel group studies were combined. In addition, sensitivity analysis was performed to evaluate the effect of the study risk of bias and of the study

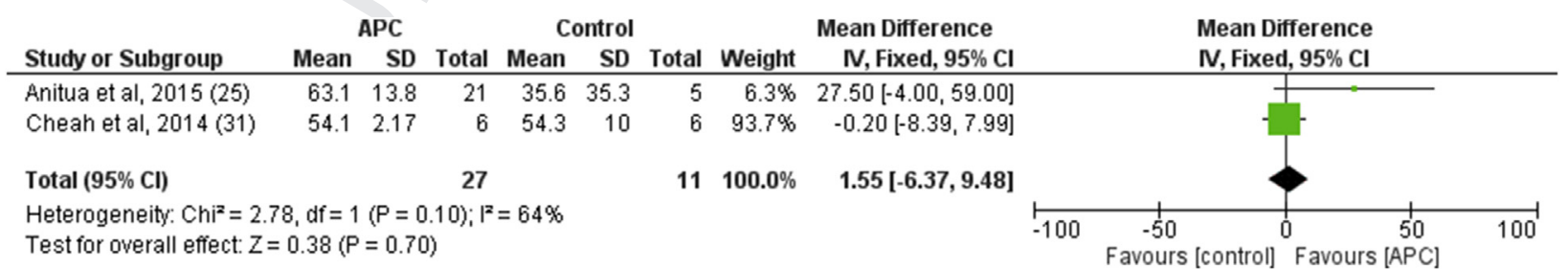

FIGURE 8. Meta-analysis of studies evaluating histomorphometric characteristics of the percentage of new bone formation at 12 postoperative weeks. APC, autologous platelet concentrate; $\mathrm{Cl}$, confidence interval; SD, standard deviation. 
DEL FABBRO ET AL

1121

1122

1123

1124

1125

1126

1127

1128

1129

1130

1131

1132

1133

1134

1135

1136

1137

1138

1139

1140

1141

1142

1143

1144

1145

1146

1147

1148

1149

1150

1151

1152

1153

1154

1155

1156

1157

1158

1159

1160

1161

1162

1163

1164

1165

1166

1167

1168

1169

1170

1171

1172

1173

1174

1175

1176

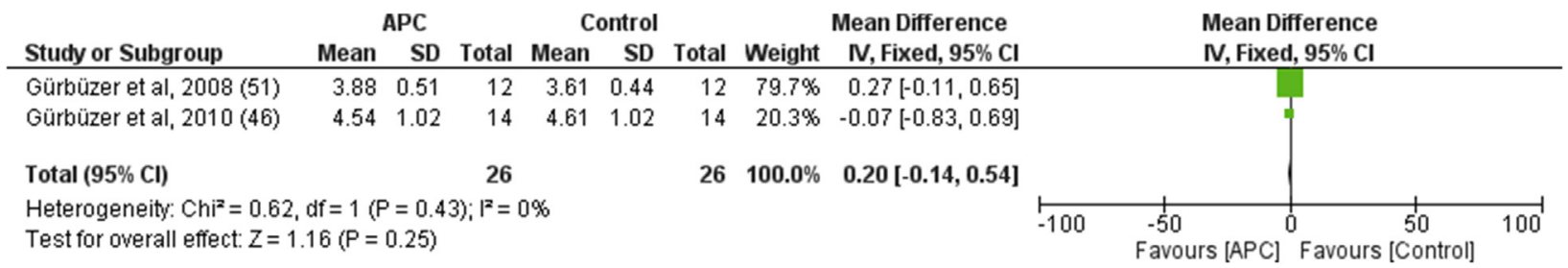

FIGURE 9. Meta-analysis of studies evaluating scintigraphic bone metabolism at 4 postoperative weeks. APC, autologous platelet concentrate; $\mathrm{Cl}$, confidence interval; $\mathrm{SD}$, standard deviation.

Del Fabbro et al. APC for Postextraction Sockets. J Oral Maxillofac Surg 2017. design (split mouth vs parallel design trial) on the overall estimates of effect.

\section{Results}

The selection process is presented in Figure 1. The electronic search retrieved 399 articles and 3 more articles were found by hand searching. After exclusion of duplicates, unrelated articles, and articles excluded for a specific reason, 33 studies met the inclusion criteria and were analyzed in this review. ${ }^{17,18,20,23-52}$

Table 1 presents the main characteristics and outcomes of the included articles. Nine articles had a parallel design and 24 had a split-mouth design. Overall, 1,193 teeth were extracted from 911 patients. Six hundred twenty postextraction sockets were treated with APCs (PRP, PRF, or PRGF) and 573 sockets served as controls (Table 1). Control sockets were left unfilled except in 3 articles in which control sockets were filled with bone graft materials (Table 1).

Table 2 presents the methodology for obtaining the APC. PRP was the APC used most frequently, followed by PRF and PRGF. All studies using PRGF adopted systematically the same procedure and used the same additives (anticoagulant and activator). ${ }^{25,36,37,41,44,47}$ Only Antonello et $\mathrm{al}^{39}$ declared that they used a modified PRGF procedure, introducing changes in many steps of the preparation technique. Conversely, protocols to obtain PRF and especially PRP varied considerably for additives, centrifugation time, and speed (Table 2).

\section{RISK-OF-BIAS ASSESSMENT}

The risk-of-bias summary is presented in Figure 2. Thirteen studies were classified as having a high risk of bias and 20 were classified as having a low risk of bias.

\section{STUDIES OUTCOMES}

Table 3 presents the qualitative summary of outcomes of all included studies. A decrease in pain levels, swelling, and patient discomfort was frequently described by the included studies, as were improved bone regeneration, bone density, and soft tissue healing.

\section{META-ANALYSIS}

\section{Soft Tissue Healing}

Index of landry. Five studies measured soft tissue healing of the postextraction alveolus at the seventh reported the standard deviation, which made the meta-analysis possible. ${ }^{17,25,27}$ The meta-analysis indicated that soft tissue healing was statistically better for sockets treated with APCs at the seventh postoperative day (mean difference, 1.01; 95\% CI, 0.77-1.24; $P<.05$; Fig 3).

Probing depth. The probing depth in the distal aspect of the second mandibular molar was measured at months 1 and 3 in 2 and 3 studies, respectively. $^{28,33,52}$ Probing depth was minor in the APC group at 2 periods in all studies. Meta-analysis indicated that this outcome was similar for the 2 groups in the first month (mean difference, -0.18 ; 95\% CI, -0.66 to $0.3 ; P>.05)$ and statistically better for the APC group at the third postoperative month (mean difference, $-1.63 ; 95 \% \mathrm{CI},-2.05$ to $-1.22 ; P<.05$; Figs 4, 5). postoperative day ${ }^{17,25,27,45,50}$; however, only 3

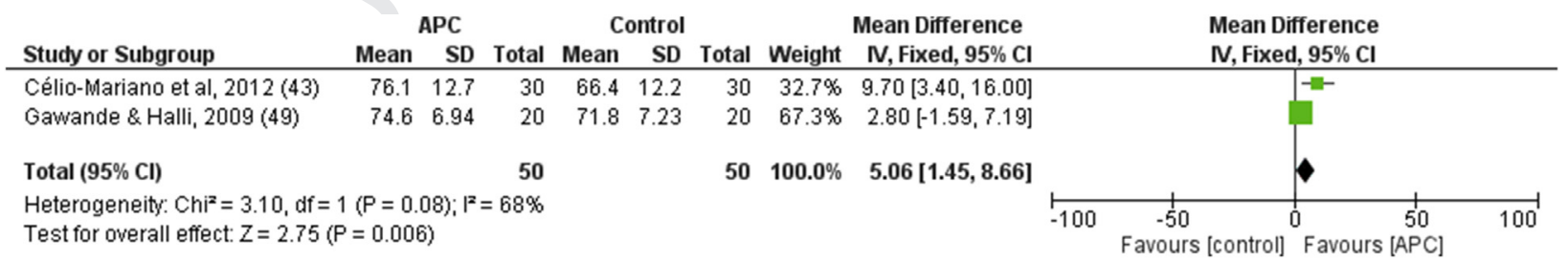

FIGURE 10. Meta-analysis of studies evaluating bone density at the first postoperative month. APC, autologous platelet concentrate; $\mathrm{Cl}$, confidence interval; SD, standard deviation.

Del Fabbro et al. APC for Postextraction Sockets. J Oral Maxillofac Surg 2017. 


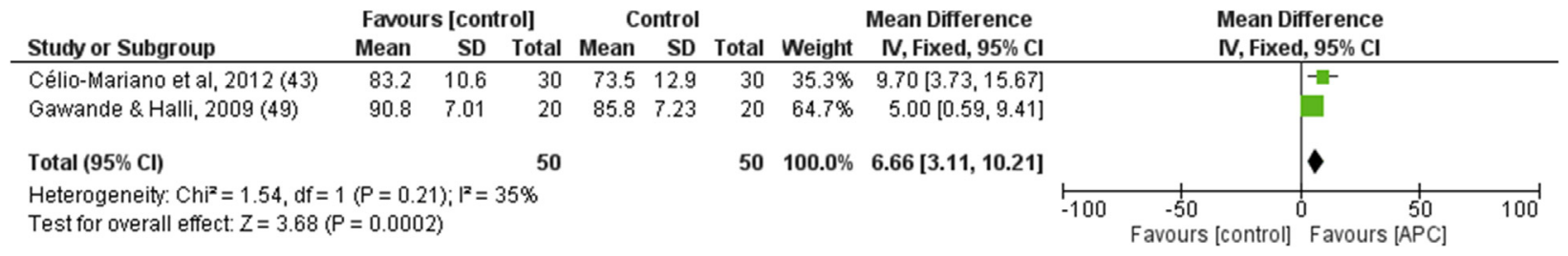

FIGURE 11. Meta-analysis of studies evaluating bone density at the third postoperative month. $\mathrm{Cl}$, confidence interval; SD, standard deviation.

Del Fabbro et al. APC for Postextraction Sockets. J Oral Maxillofac Surg 2017.

\section{Patient's Quality of Life}

Alveolar osteitis. The postextraction complication of alveolar osteitis was assessed in 10 studies, but only 4 described the event. ${ }^{17,35,40,44}$ Despite the frequency of the event, it was major in the control group (8 events in APC group [1.3\%] and 33 events in control group [5.8\%]), although the meta-analysis indicated there were no statistical differences between the APC and control groups $(\mathrm{RR}=0.20 ; 95 \%$ CI, 0.03-1.18; $P>$.05; Fig 6).

Acute Inflammation or Infection of Alveolus. Eleven studies assessed the presence of acute inflammation or infection of the postextraction socket; however, only 4 described the event. ${ }^{17,23,26,46}$ Although the event was major in the control group $(0$ event in APC group and 5 events in control group [0.9\%]), the meta-analysis indicated there were no statistical differences $(\mathrm{RR}=0.27 ; 95 \% \mathrm{CI}$, 0.06-1.27; $P<.05$; Fig 7).

Pain. Most studies measured pain through a visual analog scale of 10 points. Seven studies reported statistical differences in pain decrease for the APC group, ${ }^{17,18,23,28-30,44}$ and 5 studies described no statistical differences. ${ }^{24,42,45,49,50}$ Because of the heterogeneity of the studies and the lack of standard deviation reported by the studies, it was not possible to perform a meta-analysis for this outcome.

\section{Hard Tissue Healing}

Percentage of new bone. Two studies measured the percentage of new bone at the twelfth postoperative week through histomorphometric analysis. ${ }^{25,31} \mathrm{New}$ bone was statistically greater for the APC group in 1 study $^{25}$ and similar in the other. ${ }^{31}$ Meta-analysis indicated that the percentage of new bone formation was similar for the 2 groups (mean difference, $1.55 \%$; $95 \% \mathrm{CI},-6.37$ to $9.48 ; P>.05$; Fig 8 ).

Indirect measurement of bone metabolism. Two studies measured bone metabolism by bone scintigraphy at the fourth postoperative week. ${ }^{46,51}$ The meta-analysis showed that bone metabolism was similar for the APC and control groups, even when using 2 different APCs (mean difference, 0.20; 95\% CI, -0.14 to $0.54 ; P>.05$; Fig 9 ).

Bone density. Bone density was measured on bidimensional radiographs at the first, third, and sixth postoperative months in 2 studies. ${ }^{43,49}$ Bone density was statistically better for the APC group for all 3 periods (mean difference, 5.06; 95\% CI, 1.45-8.66; $P<.05$; mean difference, 6.66; 95\% CI, 3.11-10.21; $P<.05 ;$ mean difference, $7.29 ; 95 \%$ CI, 4.31-10.28; $P<.05$; Figs 10-12).

\section{Discussion}

Tooth extraction induces several changes in the oral physiology. The main immediate effect is a decrease in the patient's quality of life in the postsurgical period because of pain, swelling, or inflammation and sometimes alveolar infection. However, the most challenging and lasting negative effects are probably caused by alveolar bone resorption, which decreases the size of the alveolar ridges in the vertical and, mainly, horizontal dimensions. ${ }^{53}$ According to a recent review, the resorption process, triggered after tooth extraction, can cause a decrease on average of $3.79 \mathrm{~mm}$ in the horizontal dimension and a decrease of $1 \mathrm{~mm}$ in the vertical dimension at 6 months after

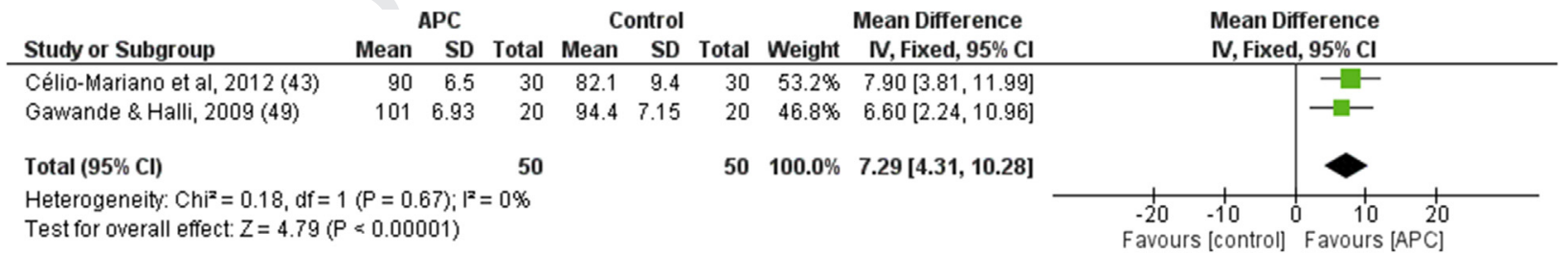

FIGURE 12. Meta-analysis of studies evaluating bone density at the sixth postoperative month. APC, autologous platelet concentrate; $\mathrm{Cl}$, confidence interval; SD, standard deviation. 
extraction. ${ }^{53}$ Moreover, it is expected to last for the patient's entire lifetime. ${ }^{3}$

Immediate and gradual effects decrease patient satisfaction with the treatment and make subsequent rehabilitation treatments difficult. Previous evidence has suggested that alveolar preservation techniques, applied soon after tooth extraction, considerably decrease bone resorption and improve the patient's quality of life. ${ }^{25}$ In this scenario, the use of APCs as a preservation technique for postextraction sockets represents a valuable, safe, and cost-effective option.

APCs are heme components (actual blood-derived products) obtained by centrifugation of the patient's own blood. What is common to all APCs is the presence of an above-baseline concentration of platelets and, hence, an increased number of growth factors available at the surgical area. ${ }^{54}$ The growth factors are endogenous soluble mediators capable of modifying the cellular response to a given stimulus. They act as intercellular signals that modulate cell function by binding to specific receptors on the cell surface of target cells. Thus, APCs promote chemotaxis, angiogenesis, proliferation, differentiation, and modulation of cells involved in the healing process.

Some APCs (PRP and PRGF) can be produced with the use of an anticoagulant and an activator and others (PRF) can be produced without the use of any additive. Thus, PRF is a complete autologous preparation. These APCs differ not only in the method for preparation but also in their biological properties.

PRP and PRGF concentrates have a relatively short duration of action because the activator induces a fast release of the granule content. Thrombin activation causes $81 \%$ of total growth factors to be released within the first day, with considerably decreased release at 3, 7, and 14 days. ${ }^{55}$ This causes a massive, fast, and short-term effect that makes the incorporation of cytokines difficult. In contrast, PRF does not need an activator to produce fibrinogen polymerization, because this occurs naturally during centrifugation. A progressive or relatively slow polymerization mode can increase the incorporation of circulating cytokines in the fibrin matrix. ${ }^{56}$ PRP releases the largest amounts of growth factors (transforming growth factor-1 [TGF-1] and platelet-derived growth factor [PDGF]) on the first day, followed by considerably decreased release at later time points. PRF releases the largest amount of TGF-1 at day 14 and the largest amount of PDGF at day $7 .^{56}$ It would be interesting to evaluate whether there are differences among the different types of concentrates for the clinical outcomes; however, this was not the objective of this study; therefore, it is not possible to recommend any specific APC preparation. In this review, 14 included studies used PRP, 13 used PRF, and 7 used PRGF or modified PRGF (Table 2). Most of the variation in outcomes among studies could be related to the use of different products that have different compositions, features, and likely different biological activities.

The objective of this systematic review was to evaluate the effect of APCs on a patient's quality of life and on soft and hard tissue healing after tooth extraction. The performed meta-analysis showed benefits of APCs for hard and soft tissue healing; bone density measured by bidimensional radiographs at 1,3 , and 6 months, index of Landry at 7 days, and probing depth at 3 months were improved. However, indirect measurement of bone metabolism, percentage of new bone, postoperative complications, and probing depth at 1 month were similar between the APC and control groups. Qualitative analysis of the outcomes reported by the included studies in general was positive for the APC group (Table 3). Decreased swelling was found in 4 of 5 studies and decreased trismus was found in 2 of 3 studies (Table 3).

The heterogeneity among studies and the lack of reported standard deviations in several studies made it impossible to perform a meta-analysis for some outcomes. For example, a marked decrease in pain for the APC group was found in 7 studies and no statistical differences for this outcome were found in 5 studies (Table 3). However, as previously described, some studies reported medians ${ }^{17}$ and others reported means, ${ }^{18,25}$ and some studies reported pain daily ${ }^{24}$ and others reported the mean of several days. ${ }^{29,30}$ Moreover, of the comparable studies, only 1 provided the standard deviation, ${ }^{25}$ which is an essential element to perform a meta-analysis. Therefore, it was not possible to perform a formal meta-analysis for this outcome, as stated in previous systematic reviews. $^{15,57}$ Thus, the actual effect of APCs on decreasing pain in extraction sockets is still not quantifiable. In the same way, bone density was measured using different techniques such as conebeam computed tomograms, ${ }^{25}$ bidimensional radiographs, ${ }^{17}$ and micro-computed tomographic methods, ${ }^{40}$ preventing a direct comparison. Nevertheless, it was possible to observe a substantial contribution of APCs to other aspects of a patient's quality of life and, mainly, to soft tissue healing after tooth extraction, which most investigators found to be enhanced.

Another common impediment for performing a meta-analysis was the heterogeneity in the follow-up duration or the postsurgical timing of when the outcomes were assessed. All these factors should be taken into consideration for future clinical studies when reporting outcomes on this subject.

Although not evaluated by the clinical studies considered, another important property of APC is its antimicrobial activity, which has been highlighted by a recent review focused on preclinical studies. ${ }^{58}$ The possibility of controlling postoperative infections is an 
important feature that could explain in part the lower incidence of complications such as alveolar osteitis and that makes APCs a clinically useful adjunctive tool.

The use of APCs can be advantageous for some relevant clinical and radiographic outcomes after a dental extraction procedure, such as increased bone density and soft tissue healing according to the performed meta-analysis and a decrease in swelling and trismus according to the qualitative analysis. The results of this systematic review showed that APCs should be used in postextraction sites to improve these clinical outcomes. The actual effect of APCs on decreasing pain in extraction sockets is still not quantifiable.

\section{References}

1. Bui CH, Seldin EB, Dodson TB: Types, frequencies, and risk factors for complications after third molar extraction. J Oral Maxillofac Surg 61:1379, 2003

2. Barone A, Ricci M, Tonelli P, et al: Tissue changes of extraction sockets in humans: A comparison of spontaneous healing vs. ridge preservation with secondary soft tissue healing. Clin Oral Implants Res 24:1231, 2013

3. Jahangiri L, Devlin H, Ting K, et al: Current perspectives in residual ridge remodeling and its clinical implications: A review. J Prosthet Dent 80:224, 1998

4. Flügge T, Nelson K, Nack C, et al: 2-Dimensional changes of the soft tissue profile of augmented and non-augmented human extraction sockets: A randomized pilot study. J Clin Periodontol 42:390, 2015

5. Vignoletti F, Matesanz P, Rodrigo D, et al: Surgical protocols for ridge preservation after tooth extraction. A systematic review. Clin Oral Implants Res 23:22, 2012

6. Chan HL, Lin GH, Fu JH, et al: Alterations in bone quality after socket preservation with grafting materials: A systematic review. Int J Oral Maxillofac Implants 28:710, 2013

7. Horvath A, Mardas N, Mezzomo LA, et al: Alveolar ridge preservation. A systematic review. Clin Oral Investig 17:341, 2013

8. Vittorini Orgeas G, Clementini M, De Risi V, et al: Surgical techniques for alveolar socket preservation: A systematic review. Int J Oral Maxillofac Implants 28:1049, 2013

9. Avila-Ortiz G, Elangovan S, Kramer KW, et al: Effect of alveolar ridge preservation after tooth extraction: A systematic review and meta-analysis. J Dent Res 93:950, 2014

10. Kassim B, Ivanovski S, Mattheos N: Current perspectives on the role of ridge (socket) preservation procedures in dental implant treatment in the aesthetic zone. Aust Dent J 59:48, 2014

11. Willenbacher M, Al-Nawas B, Berres M, et al: The effects of alveolar ridge preservation: A meta-analysis. Clin Implant Dent Relat Res 18:1248, 2016

12. Corbella S, Taschieri S, Francetti L, et al: Histomorphometric results after postextraction socket healing with different biomaterials: A systematic review of the literature and meta-analysis [published online ahead of print February 23, 2017]. Int J Oral Maxillofacial Implants. http://dx.doi.org/10.11607/jomi.5263

13. Han J, Meng HX, Tang JM, et al: The effect of different plateletrich plasma concentrations on proliferation and differentiation of human periodontal ligament cells in vitro. Cell Prolif 40: 241, 2007

14. Anitua E, Tejero R, Zalduendo MM, et al: Plasma rich in growth factors promotes bone tissue regeneration by stimulating proliferation, migration, and autocrine secretion in primary human osteoblasts. J Periodontol 84:1180, 2013

15. Del Fabbro M, Corbella S, Taschieri S, et al: Autologous platelet concentrate for post-extraction socket healing: A systematic review. Eur J Oral Implantol 7:333, 2014

16. Anitua E: Plasma rich in growth factors: Preliminary results of use in the preparation of future sites for implants. Int J Oral Maxillofac Implants 14:529, 1999
17. Alissa R, Esposito M, Horner K, et al: The influence of plateletrich plasma on the healing of extraction sockets: An explorative randomised clinical trial. Eur J Oral Implantol 3:121, 2010

18. Ogundipe OK, Ugboko VI, Owotade FJ: Can autologous plateletrich plasma gel enhance healing after surgical extraction of mandibular third molars? J Oral Maxillofac Surg 69:2305, 2011

19. Kutkut A, Andreana S, Kim HL, et al: Extraction socket preservation graft before implant placement with calcium sulfate hemihydrate and platelet-rich plasma: A clinical and histomorphometric study in humans. J Periodontol 83:401, 2012

20. Girish Rao S, Bhat P, Nagesh KS, et al: Bone regeneration in extraction sockets with autologous platelet rich fibrin gel. J Maxillofac Oral Surg 12:11, 2013

21. Moher D, Liberati A, Tetzlaff J, et al: PRISMA Group. Preferred Reporting Items for Systematic Reviews and Meta-Analyses: The PRISMA statement. Ann Intern Med 151:264, 2009

22. Higgins JPT, Green S (eds): Cochrane Handbook for Systematic Reviews of Interventions Version 5.1.0 [updated March 2011]; 2011. The Cochrane Collaboration, 2011. Available at: www. handbook.cochrane.org

23. Kumar YR, Mohanty S, Verma M, et al: Platelet-rich fibrin: The benefits. Br J Oral Maxillofac Surg 54:57, 2016

24. Ozgul O, Senses F, Er N, et al: Efficacy of platelet rich fibrin in the reduction of the pain and swelling after impacted third molar surgery: Randomized multicenter split-mouth clinical trial. Head Face Med 11:37, 2015

25. Anitua E, Murias-Freijo A, Alkhraisat MH, et al: Clinical, radiographical, and histological outcomes of plasma rich in growth factors in extraction socket: A randomized controlled clinical trial. Clin Oral Investig 19:589, 2015

26. Baslarli O, Tumer C, Ugur O, et al: Evaluation of osteoblastic activity in extraction sockets treated with platelet-rich fibrin. Med Oral Patol Oral Cir Bucal 20:e111, 2015

27. Dutta SR, Singh P, Passi D, et al: Mandibular third molar extraction wound healing with and without platelet rich plasma: A comparative prospective study. J Maxillofac Oral Surg 14:808, 2015

28. Kumar N, Prasad K, Ramanujam L, et al: Evaluation of treatment outcome after impacted mandibular third molar surgery with the use of autologous platelet-rich fibrin: A randomized controlled clinical study. J Oral Maxillofac Surg 73:1042, 2015

29. Marenzi G, Riccitiello F, Tia M, et al: Influence of leukocyte- and platelet-rich fibrin (L-PRF) in the healing of simple postextraction sockets: A split-mouth study. Biomed Res Int. http://dx. doi.org/10.1155/2015/369273

30. Uyanık LO, Bilginaylar K, Etikan I: Effects of platelet-rich fibrin and piezosurgery on impacted mandibular third molar surgery outcomes. Head Face Med 26:11, 2015

31. Cheah $\mathrm{CW}$, Vaithilingam R, Siar $\mathrm{CH}$, et al: Histologic, histomorphometric, and cone-beam computerized tomography analyses of calcium sulfate and platelet-rich plasma in socket preservation: A pilot study. Implant Dent 23:593, 2014

32. Gawai KT, Sobhana CR: Clinical evaluation of use of platelet rich plasma in bone healing. J Maxillofac Oral Surg 14:67, 2015

33. Durmuşlar MC, Alpaslan C, Alpaslan G, et al: Clinical and radiographic evaluation of the efficacy of platelet-rich plasma combined with hydroxyapatite bone graft substitutes in the treatment of intra-bony defects in maxillofacial region. Acta Odontol Scand 72:948, 2014

34. Geurs N, Ntounis A, Vassilopoulos P, et al: Using growth factors in human extraction sockets: A histologic and histomorphometric evaluation of short-term healing. Int J Oral Maxillofac Implants 29:485, 2014

35. Eshghpour M, Dastmalchi P, Nekooei AH, et al: Effect of plateletrich fibrin on frequency of alveolar osteitis following mandibular third molar surgery: A double-blinded randomized clinical trial. J Oral Maxillofac Surg 72:1463, 2014

36. Mozzati M, Gallesio G, di Romana S, et al: Efficacy of plasma-rich growth factor in the healing of postextraction sockets in patients affected by insulin-dependent diabetes mellitus. J Oral Maxillofac Surg 72:456, 2014

37. Mozzati M, Gallesio G, Gassino G, et al: Can plasma rich in growth factors improve healing in patients who underwent radiotherapy for head and neck cancer? A split-mouth study. J Craniofac Surg 25:938, 2014 
38. Suttapreyasri S, Leepong N: Influence of platelet-rich fibrin on alveolar ridge preservation. J Craniofac Surg 24:1088, 2013

39. Antonello Gde M, Torres do Couto R, Giongo CC, et al: Evaluation of the effects of the use of platelet-rich plasma (PRP) on alveolar bone repair following extraction of impacted third molars: Prospective study. J Craniomaxillofac Surg 41:e70, 2013

40. Hauser F, Gaydarov N, Badoud I, et al: Clinical and histological evaluation of postextraction platelet-rich fibrin socket filling: A prospective randomized controlled study. Implant Dent 22: 295, 2013

41. Farina R, Bressan E, Taut A, et al: Plasma rich in growth factors in human extraction sockets: A radiographic and histomorphometric study on early bone deposition. Clin Oral Implants Res 24: 1360,2013

42. Batstone MD, Cosson J, Marquart L, et al: Platelet rich plasma for the prevention of osteoradionecrosis. A double blinded randomized cross over controlled trial. Int J Oral Maxillofac Surg 41:2, 2012

43. Célio-Mariano R, de Melo WM, Carneiro-Avelino C: Comparative radiographic evaluation of alveolar bone healing associated with autologous platelet-rich plasma after impacted mandibular third molar surgery. J Oral Maxillofac Surg 70:19, 2012

44. Haraji A, Lassemi E, Motamedi MH, et al: Effect of plasma rich in growth factors on alveolar osteitis. Natl J Maxillofac Surg 3:38, 2012

45. Singh A, Kohli M, Gupta N: Platelet rich fibrin: A novel approach for osseous regeneration. J Maxillofac Oral Surg 11:430, 2012

46. Gürbüzer B, Pikdöken L, Tunali M, et al: Scintigraphic evaluation of osteoblastic activity in extraction sockets treated with platelet-rich fibrin. J Oral Maxillofac Surg 68:980, 2010

47. Mozzati M, Martinasso G, Pol R, et al: The impact of plasma rich in growth factors on clinical and biological factors involved in healing processes after third molar extraction. J Biomed Mater Res A 95:741, 2010

48. Arenaz-Búa J, Luaces-Rey R, Sironvalle-Soliva S, et al: A comparative study of platelet-rich plasma, hydroxyapatite, demineralized bone matrix and autologous bone to promote bone regeneration after mandibular impacted third molar extraction. Med Oral Patol Oral Cir Bucal 15:e483, 2010

49. Gawande PD, Halli R: Efficacy of platelet rich plasma in bone regeneration after surgical removal of impacted bilateral mandibular third molars: Pilot study. J Maxillofac Oral Surg 8: 301, 2009

50. Vivek GK, Sripathi Rao BH: Potential for osseous regeneration of platelet rich plasma: A comparative study in mandibular third molar sockets. J Maxillofac Oral Surg 8:308, 2009

51. Gürbüzer B, Pikdöken L, Urhan M, et al: Scintigraphic evaluation of early osteoblastic activity in extraction sockets treated with platelet-rich plasma. J Oral Maxillofac Surg 66:2454, 2008

52. Sammartino G, Tia M, Marenzi G, et al: Use of autologous platelet-rich plasma (PRP) in periodontal defect treatment after extraction of impacted mandibular third molars. J Oral Maxillofac Surg 63:766, 2005

53. Tan WL, Wong TL, Wong MC, et al: A systematic review of postextractional alveolar hard and soft tissue dimensional changes in humans. Clin Oral Implants Res 23(suppl 5):1, 2012

54. Marx RE, Carlson ER, Eichstaedt RM, et al: Platelet-rich plasma: Growth factor enhancement for bone grafts. Oral Surg Oral Med Oral Pathol Oral Radiol Endod 85:638, 1998

55. Tsay RC, Vo J, Burke A, et al: Differential growth factor retention by platelet-rich plasma composites. J Oral Maxillofac Surg 63: 521, 2005

56. He L, Lin Y, Hu X, et al: A comparative study of platelet-rich fibrin (PRF) and platelet-rich plasma (PRP) on the effect of proliferation and differentiation of rat osteoblasts in vitro. Oral Surg Oral Med Oral Pathol Oral Radiol Endod 108:707, 2009

57. Del Fabbro M, Bortolin M, Taschieri S: Is autologous platelet concentrate beneficial for post-extraction socket healing? A systematic review. Int J Oral Maxillofac Surg 40:891, 2011

58. Del Fabbro M, Bortolin M, Taschieri S, et al: Antimicrobial properties of platelet-rich preparations. A systematic review of the current pre-clinical evidence. Platelets 27:276, 2016 